\title{
Prevalence and Path Analysis on the Effects of Diarrhea and Life Course Determinants on Stunting in Children Under Two Years of Age in Kupang, East Nusa Tenggara
}

\author{
Nabilah Nurul Ilma'), Harsono Salimo²), Eti Poncorini Pamungkasari²) \\ 1)Masters Program in Public Health, Universitas Sebelas Maret \\ 2)Faculty of Medicine, Universitas Sebelas Maret
}

\begin{abstract}
Background: The interaction between infections and malnutrition has been recognized as a vicious cycle. Repeated diarrhoeal illnesses as well as other common childhood infections progressively altered the normal growth trajectories of children. This study aimed to analyze the effects of diarrhea and lifelong determinants on the incidence of stunting in children under two years in Kupang.

Subjects and Method: This was a case control study conducted in 25 integrated health posts in Alak and Oebobo Subdistricts, in Kupang, East Nusa Tenggara, from November December 2018. A sample of 200 children under two years was selected by multi-stage random sampling. The dependent variable was stunting. The independent variables were diarrhea, birth length, parental income, maternal education, exclusive breastfeeding, maternal height, maternal mid-upper arm circumference (MUAC), complementary feeding, maternal hygiene practice, and sanitation. The data were collected by questionnaire and analyzed by path analysis.

Results: Stunting prevalence in Kupang was 30.5\%. The risk of stunting was directly decreased by appropriate complementary feeding $(b=-1.97 ; 95 \% \mathrm{CI}=-3.55$ to $-0.39 ; \mathrm{p}=0.014)$, good hygiene practice $(b=-4.38 ; 95 \% \mathrm{CI}=-6.63$ to $-2.12 ; \mathrm{p}<0.001)$, good sanitation $(\mathrm{b}=-2.32 ; 95 \% \mathrm{CI}=-4.00$ to $-0.64 ; \mathrm{p}=0.007)$, and birth length $\geq 48 \mathrm{~cm}(\mathrm{~b}=-2.22 ; 95 \% \mathrm{CI}=-3.74$ to $-0.69 ; \mathrm{p}=0.004)$. The risk of stunting was directly increased by diarrhea $(b=2.55 ; 95 \% \mathrm{CI}=1.01$ to $4.09 ; \mathrm{p}=0.001)$. It was indirectly affected by parental income, maternal education, exclusive breastfeeding, maternal height, and maternal MUAC at pregnancy.

Conclusion: The risk of stunting is directly decreased by appropriate complementary feeding, good hygiene practice, good sanitation, and birth length $\geq 48 \mathrm{~cm}$. The risk of stunting is directly increased by diarrhea. It is indirectly affected by parental income, maternal education, exclusive breastfeeding, maternal height, and maternal MUAC at pregnancy.
\end{abstract}

Keywords: stunting, determinants, prevalence, diarrhea

\section{Correspondence:}

Nabilah Nurul Ilma. Masters Program in Public Health. Universitas Sebelas Maret, Jl. Ir. Sutami 36A, Surakarta 57126, Central Java, Indonesia. Email: nabilahnurul86@gmail.com.

Mobile: +6287838555468 .

\section{BACKGROUND}

Stunting illustrates the occurrence of longstanding nutritional problems. Globally, in 2017, there are 150.8 million or $22.2 \%$ of children under the age of 5 experience stunting (WHO/UNICEF/World Bank, 2018). In Indonesia, the stunting prevalence is estimated to reach $30.8 \%$. This makes Indonesia one of the countries with a high prevalence of stunting and indicates that there is still a high chronic nutrition problem in the community (Riskesdas, 2018; WHO, 2012; Ministry of Health, 2018).

East Nusa Tenggara is a province in Indonesia with the highest percentage of stunting occurrences among toddlers, which is $42.6 \%$ in 2017 . This figure actually increases when compared to 2016, which 
was 38.75\% (Riskesdas, 2018; Ministry of Health, 2018). Stunting in infants is a picture of a disturbance in the first 1,000 days of birth. The 2018 Basic Health Research Report shows an increase in the prevalence of Indonesian patients aged 0 23 months with short (very short and very short) nutritional status from $21.7 \%$ in 2016 to $29.9 \%$ (Riskesdas, 2018; RI Ministry of Health, 2018).

The province of East Nusa Tenggara has a high prevalence of stunting in children aged 0-23 months at 29.8\%. According to the East Nusa Tenggara health office, the percentage of stunting in children aged o23 months in Kupang, which is the capital city of the NTT province, is 25\% (NTT Health Office, 2018).

Various problems can be caused from children who experience stunting, including minimizing the possibility of survival, disruption of body metabolism, reduced cognitive and physical development, reduced productive capacity and poor health. Stunting children cannot optimize their growth and development, these effects provide long-term effects that will affect throughout the life of the child (UNICEF, 2013; Ministry of Health, 2016; WHO, 2014).

Stunting is a result of inadequate nutrition and recurrent infection attacks during the first two years of life (WHO, 2014; Brinkman et al., 2009). The casecontrol study conducted in southern Ethiopia shows that exposure to diarrheal disease is a factor that is significantly associated with stunting (Batiro, et al, 2017). Children who suffer from diarrhea will experience malabsorption of nutrients, during diarrhea appetite will decrease with decreasing absorption of nutrients from the intestine and if not immediately followed up and balanced with appropriate intake will occur failure to grow (Desyanti and
Nindya, 2017; Tomkins \& Watson, 1989 in Jamro, et al, 2012).

Diarrhea itself is the number one cause of death in infants and toddlers (Indonesian Ministry of Health, 2013). Indonesia's health profile in 2017 shows the incidence of diarrhea in Indonesia amounting to 7,077,299 and cases handled by 60.4\%. In NTT Province, the incidence of diarrhea recorded was 142,757 with $32.3 \%$ of cases handled. This makes NTT one of the provinces with a low percentage of cases of diarrhea handling (Ministry of Health, Republic of Indonesia, 2018). Based on data from Kupang health service in 2017, diarrheal diseases are among the 10 most diseases in Kupang. The monthly recapitulation results in 2017 show the incidence of diarrhea in infants amounting to 4,263 cases. One of the causes of diarrhea events is sanitation and clean water (Budhathoki, et al, 2016; Rahman, et al, 2016).

According to UNICEF (2013), the interaction between malnutrition and infection will create a dangerous cycle that has the potential to worsen disease conditions and nutritional status. This is caused by the loss of fluid and electrolytes, loss of appetite, the body is difficult to absorb nutrients so that growth is hampered (Batiro, et al, 2017; Ministry of Health Republic of Indonesia, 2016).

Kupang as the capital of East Nusa Tenggara Province has various advantages in terms of health facilities, availability of foodstuffs and so on, but this is not a guarantee that Kupang is free from nutritional problems, especially in children under two years. The still high incidence of stunting in the capital indicates that nutrition problems in the community have been going on for a long time and have not been fully resolved (City of Kupang Health Office, 2018). Therefore, the researchers intend to examine the effect of diarrhea and lifelong 
Journal of Maternal and Child Health, 2019, 4(4): 230-241

https://doi.org/10.26911/thejmch.2019.04.04.02

determinants on the incidence of stunting in children under two years in Kupang.

\section{SUBJECTS AND METHOD}

\section{Study Design}

This study used an observational analytic design. The approach is done in a case control. This study was conducted in 25 posyandu in Alak and Oebobo Sub-districts, Kupang, from November to December 2018.

\section{Population and Samples}

The source population in this study was all children aged 6 - 23 months in the Alak sub-district and Oebobo sub-district in Kupang City. The samples studied were 200 research subjects.

\section{Study variables}

The dependent variable in this study is Stunting. The independent variables in this study are parental income and maternal education, maternal height, maternal MUAC during pregnancy, maternal hygiene practices, basic sanitation, birth length, diarrhea, exclusive breastfeeding and complementary feeding.

\section{Operational Definition of Variables}

Stunting is defined as a nutritional status that is classified as short based on indicators of body length according to age using z-score WHO 2005 standard. The measuring instruments used were length board / infantometer with continuous scale, then converted into dichotomies for data analysis needs with code o for normal babies and 1 for stunting babies.

Mother's education is defined as the highest formal school experience that is followed or pursued based on the last diploma obtained by the mother. The measuring instrument used was an individual questionnaire with a categorical scale. Code $\mathrm{o}$ is if the subject has a basic education (elementary and junior high school or equivalent) and 1 is if the subject is highly educated (high school or equivalent and college).

Parental income is defined as the total income of the father and mother received in the form of money from work in 1 month. The measuring instrument used was in the form of a parent income questionnaire with a continuous scale, which then was converted into a dichotomy for data analysis needs with code o for low income $(<$ minimum wage) and 1 for high income ( $\geq$ minimum wage).

Birth length is defined as the length of the baby's body at birth which is measured in the first hour of birth, expressed in centimeters $(\mathrm{cm})$ and recorded in the $\mathrm{MCH} /$ KMS book. The measuring instruments were individual questionnaires (seen from the MCH / KMS book) on a continous scale which then was converted into dichotomous for data analysis needs with code 0 for short $(<48 \mathrm{~cm})$ and 1 for normal $(\geq 48$ $\mathrm{cm})$.

Diarrhea is defined as a disease that has been suffered in the form of defecation amounting to 3 or more times for 24 hours with flaccid consistency to liquid which occurs more than 2 times in the last 6 months. The measuring instrument used was diarrheal disease questionnaireswith a categorical scale with code $\mathrm{o}$ for not diarrhea and o fordiarrhea.

The practice of maternal hygiene is defined as the actions of mothers to maintain children's hygiene and health, including hand washing practices, food sanitation, nail hygiene and home environment in order to achieve children's physical and psychological well-being. The measurement scale was dichotomous for data analysis needs with code $o$ for the hygiene whichis lacking (score <mean) and 1 for hygiene which is good (score $\geq$ mean).

Basic sanitation is defined as a household sanitation facility that includes the 
provision of clean water, defecation facileties, waste management facility and household waste. The measuring instrument used was in the form of a basic scale continuous sanitation questionnaire which was then changed to a dichotomy for data analysis needs with code $\mathrm{o}$ for lacking sanitation $(<$ mean) and 1 forgood sanitation ( $\geq$ mean).

Exclusive breastfeeding is defined as giving only breast milk to babies from birth to 6 months of age. The measuring instrument used was an exclusive breastfeeding questionnaire with a categorical scale withcode $\mathrm{o}$ for not exclusive breastfeeding and 1 for exclusive breastfeeding.

Complementary feeding is defined as the practice of providing food / drinks other than breast milk by the mother or caregiver to toddlers. The measuring instrument used was in the form of a continuous scale MPASI questionnaire which was then changed to a dichotomy for data analysis needs withcode $o$ forlacking (score $<$ mean) and 1 for good (score $\geq$ mean).

Maternal height is defined as the maternal linear body size measured from toe to head in centimeters $(\mathrm{cm})$. The measuring instrument used was in the form of an individual questionnaire (seen from the $\mathrm{MCH}$ handbook) with a continuous scale which was then converted into a dichotomy for the needs of data analysis with code ofor short $(<150 \mathrm{~cm})$ and 1 for normal $((15 \mathrm{Ocm})$.

Maternal MUAC during pregnancy is defined as a measure of the upper arm circumference of the mother during pregnancy measured by using a measuring tape made of fiberglass expressed in units of centimeters $(\mathrm{cm})$ and recorded in the $\mathrm{MCH}$ book. The measurement scale was dichotomous, coded o for $<23.5 \mathrm{~cm}$ and 1 for $\geq$ $23.5 \mathrm{~cm}$.

\section{Data Analysis}

Data analysis in this study employs path analysis with the STATA program 13. Path analysis is used to determine the magnitude of the influence of other variables, both direct and indirect effects. The steps in analyzing the data using path analysis include model specifications, model identification, model suitability, parameter estimation, and model specification.

\section{Research Ethics}

The research ethics used in this study is the approval sheet by the research subjects, without names, confidentiality, benefits, and approval of ethical feasibility (Ethical Clearance) from the Health Research Ethics Commission of the Faculty of Medicine, SebelasMaret University.

\section{RESULTS}

\section{Sample Characteristics}

Table 1 shows the characteristics of the research subjects. The age characteristics of the study subjects were mostly 13-23 months, namely 108 subjects (54\%) and the gender characteristics of the study subjects were mostly women, namely 102 subjects (51\%).

Table 1. Sample Characteristics

\begin{tabular}{lcc}
\hline Characteristics & n & $\%$ \\
\hline Children Age & & \\
$6-12$ & 92 & 46.0 \\
$13-23$ & 108 & 54.0 \\
Gender & & \\
Male & 98 & 49.0 \\
Female & 102 & 51.0 \\
\hline
\end{tabular}

\section{Univariate Analysis}

Table 2 shows that children with short birth lengths were 65 subjects (32.5\%) while children with normal birth lengths were 135 subjects (67.5\%). Maternal height $(<150 \mathrm{Om})$ were 33 subjects (16.5\%) while mothers with normal height $(\geq 150 \mathrm{~cm})$ were 167 subjects (83.5\%). The mother had a basic education with 91 subjects (45.5\%) while the higher educated mothers numbered 109 subjects (54.5\%). Parents with low income 
Journal of Maternal and Child Health, 2019, 4(4): 230-241

https://doi.org/10.26911/thejmch.2019.04.04.02

amount to 104 subjects (52\%) while highincome parents have 96 subjects (48\%).

Table 2. Univariate Analysis



Non-exclusive breastfeeding amounts to $33(16.5 \%)$ while exclusive breastfeeding amounts to 167 subjects (83.5\%). Inappropriate complementary feeding was 86 (43\%). Diarrhea was experienced by 69 subjects (34.5\%). The practice of hygiene of mothers was 97 (48.5\%) while the practice of maternal hygiene was 103 (51.5\%). Poor basic sanitation is 96 subjects (48\%) while good basic sanitation is 104 subjects (52\%). Materna MUAC at pregnancy $<23.5 \mathrm{~cm}$ was 59 (29.5\%) while maternal MUAC at pregnancy $\geq 23.5 \mathrm{~cm}$ were $141(70.5 \%)$.

\section{The results of path analysis}

Figure 1 depicted path analysis model with estimation. Figure 1 showed that measured variable was 11, endogenous variable was 8 , and exogenous variable was 3 . The degree of freedom $(\mathrm{df})=38$ (over-identified).

Table 3 showed the results of path analysis. Appropriate complementary feeding reduced the risk of stunting $(b=-1.97$; $95 \% \mathrm{CI}=-3.55$ to $-0.39 ; \mathrm{p}=0.014)$.

Good maternal hygiene reduced the risk of stunting $(\mathrm{b}=-4.38 ; 95 \% \mathrm{CI}=-6.63$ to $-2.12 ; \mathrm{p}<0.001$ ). 
Good basic sanitation affects reduced the risk of stunting $(b=-2.32 ; 95 \% \mathrm{CI}=$ 4.00 to $-0.64 ; \mathrm{p}=0.007)$.

Child's birth length was associated with stunting. Birth length $\geq 48 \mathrm{~cm}$ reduced the risk of stunting $(b=-2.22 ; 95 \% C I=-3.74$ to $0.69 ; \mathrm{p}=0.004)$.

The incidence of recurrent diarrhea affected the risk of stunting. Children who experienced recurrent diarrhea increase the risk of stunting $\mathrm{b}=2.55 ; 95 \% \mathrm{CI}=1.01$ to 4.09; $\mathrm{p}=0.001$ ).

Mothers who gave exclusive breastfeeding could increase the provision of good complemenary food $(b=1.39 ; 95 \% \mathrm{CI}=0.51$ to $2.28 ; \mathrm{p}=0.002)$.

Parents income affected the provision of complemenary food. Parents who have high income would increase the provision of complementary feeding ( $b=1.81 ; 95 \%$ $\mathrm{CI}=1.16$ to $2.46 ; \mathrm{p}<0.001)$.

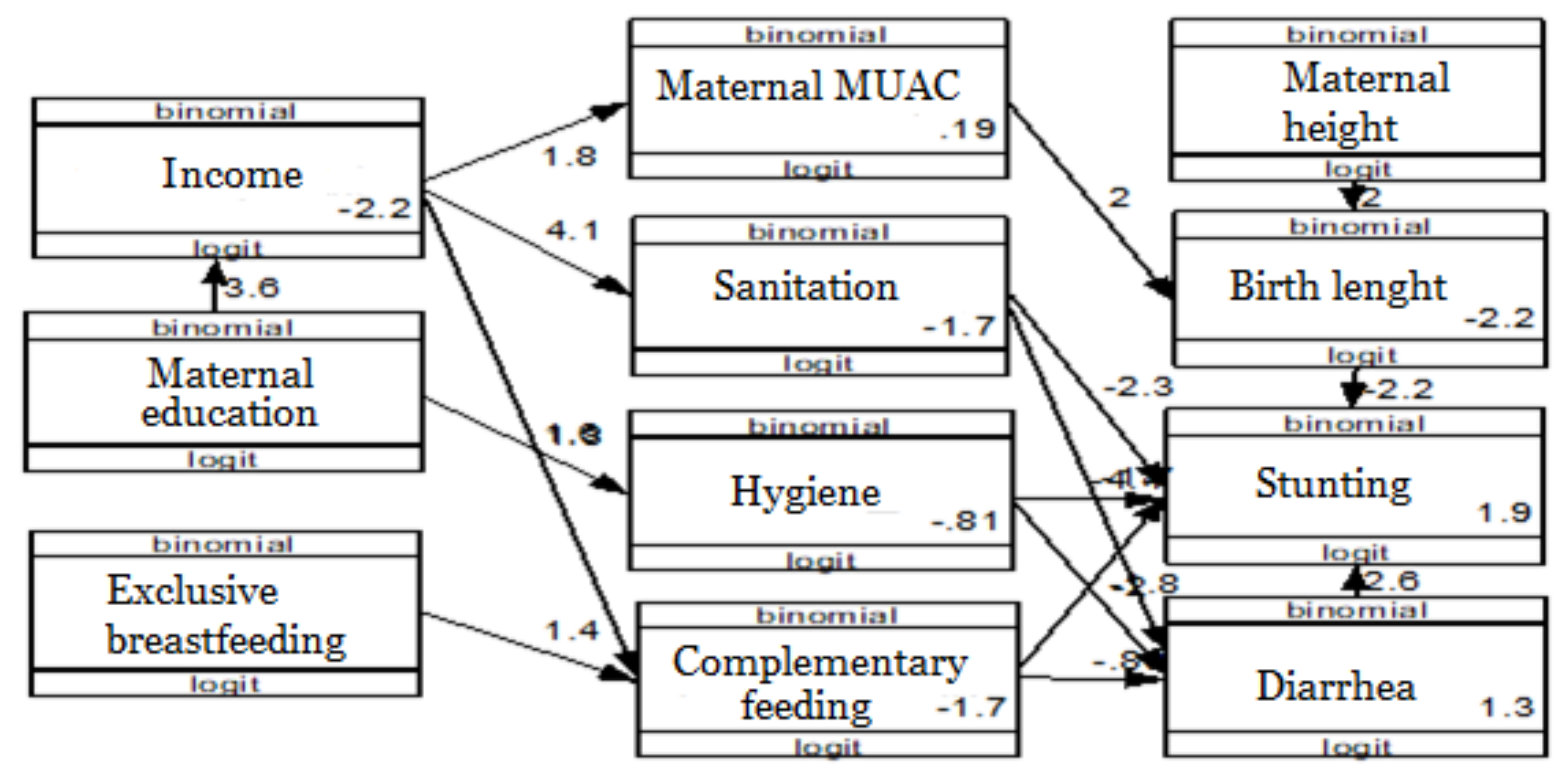

Figure 1. Structural Model with Estimate

Maternal hygiene practice affected the risk of diarrhea. Mothers who have good hygiene practice would decrease the risk of recurrent diarrhea in children $(b=-1.8395 \%$ $\mathrm{CI}=-2.65$ to $-1.01 ; \mathrm{p}<0.001$ )

The provision of complemenary food affected the risk of diarrhea. The provision of good complemenary food would decrease the risk of recurrent diarrhea in children $(\mathrm{b}=-0.89 ; 95 \% \mathrm{CI}=-1.68$ to $-0.09 ; \mathrm{p}=$ 0.028).

Basic sanitation affected the risk of diarrhea in children. Family who have good basic sanitation decreased the risk of recurrent diarrhea in children $(b=-1.73$; 95\% $\mathrm{CI}=-2.57$ to -0.88 ; $\mathrm{p}<0.001$.)
Basic sanitation affected maternal hygiene practice. Good basic sanitation increased good maternal hygiene practice to the children $(b=1.50 ; 95 \% \mathrm{CI}=0.80$ to 2.20; $\mathrm{p}<0.001$ ).

Maternal education affected maternal hygiene practice. Highly-educated mothers increased good maternal hygiene practice $(b=0.88 ; 95 \% \mathrm{CI}=0.18$ to $1.58 ; \mathrm{p}=0.014$ )

Maternal height affected child birth length. Maternal height $\geq 150 \mathrm{~cm}$ increased the likelihood of having children with birth length of $\geq 48 \mathrm{~cm} \mathrm{(b=2.03;95 \%} \mathrm{CI=1.08} \mathrm{to}$ 2.98; $\mathrm{p}<0.001$ ).

Maternal MUAC affected children's birth length. Mothers with MUAC $\geq 23.5$ increased the likelihood of having children 
Journal of Maternal and Child Health, 2019, 4(4): 230-241

https://doi.org/10.26911/thejmch.2019.04.04.02

with birth length of $\geq 48 \mathrm{~cm}(\mathrm{~b}=1.97 ; 95 \%$ $\mathrm{CI}=1.24$ to 2.70 ; $\mathrm{p}<0.001)$.

Parental income affected basic sanitation. High income increase the likelihood of good basic sanitation $(b=4.10$; $95 \% \mathrm{CI}=$ 3.20 to 5.00 ; $\mathrm{p}<0.001$ )

Parental income affected maternal MUAC. High income increased the likeli-

Table 4. The Results of Path Analysis

\begin{tabular}{|c|c|c|c|c|c|c|}
\hline \multirow[b]{2}{*}{ DependentVariable } & & \multirow[b]{2}{*}{ Independent Variable } & \multirow[b]{2}{*}{ b } & \multicolumn{2}{|c|}{ CI 95\% } & \multirow[b]{2}{*}{$\mathbf{p}$} \\
\hline & & & & $\begin{array}{l}\text { Lower } \\
\text { Limit }\end{array}$ & $\begin{array}{l}\text { Upper } \\
\text { Limit }\end{array}$ & \\
\hline \multicolumn{7}{|l|}{ Direct Effect } \\
\hline Stunting & $\leftarrow$ & Complementary Food & -1.97 & $-3 \cdot 55$ & -0.39 & 0.014 \\
\hline Stunting & $\leftarrow$ & $\begin{array}{l}\text { Maternal hygiene } \\
\text { practices }\end{array}$ & $-4 \cdot 38$ & -6.63 & -2.12 & $<0.001$ \\
\hline Stunting & $\leftarrow$ & Basic sanitation & -2.32 & -4.00 & -0.64 & 0.007 \\
\hline Stunting & $\leftarrow$ & Diarrhea & 2.55 & 1.01 & 4.09 & 0.001 \\
\hline Stunting & $\leftarrow$ & Birth Length & -2.22 & -3.74 & -0.69 & 0.004 \\
\hline \multicolumn{7}{|l|}{ Indirect Effect } \\
\hline Complementary Food & $\leftarrow$ & Exclusive breastfeeding & 1.39 & 0.51 & 2.28 & 0.002 \\
\hline Complementary Food & $\leftarrow$ & Parents income & 1.81 & 1.16 & 2.46 & $<0.001$ \\
\hline Diarrhea & $\leftarrow$ & Complementary Food & -0.89 & -1.68 & -0.09 & 0.028 \\
\hline Diarrhea & $\leftarrow$ & Basic sanitation & -1.73 & -2.57 & -0.88 & $<0.001$ \\
\hline Diarrhea & $\leftarrow$ & $\begin{array}{l}\text { Maternal hygiene } \\
\text { practices }\end{array}$ & -1.83 & -2.65 & -1.01 & $<0.001$ \\
\hline $\begin{array}{l}\text { Maternal hygiene } \\
\text { practices }\end{array}$ & $\leftarrow$ & Basic sanitation & 1.50 & 0.80 & 2.20 & $<0.001$ \\
\hline $\begin{array}{l}\text { Maternal hygiene } \\
\text { practices }\end{array}$ & $\leftarrow$ & Maternal education & 0.88 & 0.18 & 1.58 & 0.014 \\
\hline Basic sanitation & $\leftarrow$ & Parents income & 4.10 & 3.20 & 5.00 & $<0,001$ \\
\hline Birth Length & $\leftarrow$ & Maternal height & 2.03 & 1.08 & 2.98 & $<0,001$ \\
\hline Birth Length & $\leftarrow$ & $\begin{array}{l}\text { Maternal MUAC during } \\
\text { pregnancy }\end{array}$ & 1.97 & 1.24 & 2.70 & $<0,001$ \\
\hline $\begin{array}{l}\text { Maternal MUAC } \\
\text { during pregnancy }\end{array}$ & $\leftarrow$ & Parents income & 1.75 & 1.03 & 2.47 & $<0.001$ \\
\hline $\begin{array}{l}\text { Parents income } \\
\text { Number of obs }=200 \\
\text { Log likelihood }=-699 .\end{array}$ & $\leftarrow$ & Maternal education & 3.58 & 2.75 & 4.41 & $<0.001$ \\
\hline
\end{tabular}

\section{DISCUSSIONS}

\section{Stunting prevalence}

Based on the results of this study, the prevalence of stunting in children under two years old in Kupang was $30.5 \%$. This finding was slightly higher compared to the prevalence of stunting in children $0-23$ months old according to the East Nusa Tenggara health service, which was $25 \%$. hood of maternal MUAC $\geq 23.5 \mathrm{~cm} \mathrm{(b=}$ $1.75 ; 95 \% \mathrm{CI}=1.03$ to $2.47 ; \mathrm{p}<0.001$ )

Maternal education affected family income. Highly-educated mothers increase the likelihood of high family income ( $b=$ $3.58 ; 95 \% \mathrm{CI}=2.75$ to $4.41 ; \mathrm{p}<0.001)$.$$
\text { (n) }
$$ 
stunting. The results of a study conducted by Desyanti and Nindya (2017) also explained that toddlers who often experience diarrhea in the last 3 months have a risk by 3,619 times to have stunting.

Stunting was the result of inadequate nutrition and recurrent infection attacks during the first two years of life (WHO, 2014; Brinkman et al., 2009). Children suffering from diarrhea would experience malabsorption of nutrients, during the diarrhea, they would lose their appetite with decreased absorption of nutrients from the intestine and if it was not immediately followed up and balanced with the appropriate intake, the failure of growing would occur (Desyanti and Nindya, 2017; Tomkins and Watson, 1989 in Jamro, et al, 2012).

\section{The effect of basic sanitation on the incidence of stunting}

The result of this study showed that there was an effect of basic sanitation on the incidence of stunting. Households that have good basic sanitation can reduce the risk of stunting. This result was in line with the study conducted by Torlesse et al. (2016), which stated that household sanitation and drinking water treatment were strong predictors of stunting in children aged o-23 months old in Indonesia. Children from households that did not have good water and sanitation facilities were at a higher risk for stunting (Merchant et al., 2003; in cahyono, 2016). This study was also relevant to the study of Sulaiman, et al., (2018) in North Sudan, which stated that the risk of stunting was higher among children who live in poor household sanitation.

Good sanitation was very important in reducing morbidity and mortality, especially in toddlers who were still vulnerable. A study conducted in India stated that household access to toilet facilities was associated with a reduced likelihood of stunting $16-39 \%$ in children aged $0-23$ months old (Rah, et al, 2015). Children in households with access to high-quality sanitation were $13 \%$ less likely to suffer from diarrhea in the short term, and almost 27\% were less likely to become stunted (Fink et al, 2011).

Safe water prevented the development of water-borne diseases, and sanitation and hygiene can affect the health and nutrition status of children (Hunter et al., 2010; in kavosi et al., 2014). More evidences showed that there was a relationship between children's linear growth and sanitation practices in the children's house (Aguayo \& Menon, 2016)

Mbuya and Humphrey (2016), suggested to conduct baby-WASH intervention (improved sanitation and water, hand washing with soap, ensuring clean toys and the environment for providing baby food and food hygiene) to prevent oral transmission that occurred in the first two years from a child's life, as an effort to reduce global stunting.

\section{The effect of maternal hygiene practice on the incidence of stunting}

The result of this study showed that there was an effect of maternal hygiene practice on the incidence of stunting. Good maternal hygiene practices can reduce the risk of stunting in children. These results were in line with several studies which stated that there was a significant relationship between the practice of hygiene and the incidence of stunting (Desyanti \& Nindya, 2017; Niga \& Purnomo, 2016). Children who were cared for with poor hygiene would be at risk of stunting by 4.808 times greater than children who were nurtured with good hygiene (Desyanti \& Nindya, 2017).

Mother/caregiver hygiene practices such as washing hands with soap before eat or after defecation were associated with a 
$15 \%$ reduction in the risk of stunting (Rah et al, 2015). WASH influenced the stunting through direct biological mechanisms by reducing the risk of symptomatic and asymptomatic enteric infections and by social and economic mechanisms (Cumming \& Cairncross, 2016).

The protective effect of maternal/ nanny hygiene practices was stronger when accompanied by better household access to water and toilet facilities. Efforts to improve the practice of hand washing from mothers/caregivers and children were very important to prevent diarrhea and other infections among children, which in turn can contribute to the reduction of stunting. This effort must be accompanied by concrete actions to improve household water and sanitation conditions (Rah et al., 2015).

\section{The effect of birth length on the incidence of stunting}

The result of this study showed that there was an effect of birth length on the incidence of stunting. Children with normal birth length $(\geq 48 \mathrm{~cm})$ reduce the incidence of stunting. This study was in line with a study in Indonesia (Schmidt et al., 2002), which stated that the length of a newborn was a strong determinant of the body length of a child at 12 months old compared to other factors studied (de Onis \& Branca, 2016).

Similar results were also shown by research conducted by Ayuningrum (2017) and Indriyani (2018), which stated that birth length was significantly associated with the incidence of stunting, where children born with a body length of $<48 \mathrm{~cm}$ can increase the risk of stunting. Birth growth deficits significantly increased the risk of stunting for up to 2 years of life and contributed to short stature and increase the risk of future chronic diseases (Aryastami et al, 2017).

\section{The effect of complementary feed- ing on the incidence of stunting}

The result of this study showed that there was an effect of complementary feeding on the incidence of stunting. Provision of good complementary food would reduce the risk of stunting in children. This was in line with the research conducted by Humphrey, et al., (2018) which stated that the intervention of supplementary feeding increased linear growth and reduced stunting by $21 \%$. Complementary feeding interventions have a significant relationship to linear growth and the intervention of complementary feeding also has an impact on the growth of children aged 6-23 months old in low and middle income countries (Panjwani \& Heudkamp, 2017).

A study in Ethiopia suggested that mothers with obstructed children have breastfeeding practices and complementary feeding that were worse and less responsive than caregivers with children who were not hampered (Abebe et al., 2017). Children under the age of 2 years old also have high nutritional needs to support growth and development. Babies need complementary foods with a high nutrient density (the amount of each nutrient per $100 \mathrm{kcal}$ ) than adult diet. Babies must receive the most nutrient-rich foods in the household. Increased intake of nutrient-rich foods, as well as increased practice of providing complementary foods can improve the diet during the first 1000 days of life (Dewey, 2013; Vitta and Dewey 2013; in dewey, 2016).

The age period of 6 to 24 months old was one of the most critical periods for linear growth and was a period of peak stunting prevalence in developing countries, due to the high demand for nutrients and the limited quality and quantity of complementary foods. Supplementary feeding refer to the timely introduction of safe 
and nutritious food in addition to sustainable breastfeeding (Shrimpton et al., 2001; Dewey et al., 2008; WHO, 2003; in Prendergast \& Humphrey, 2014). In addition to the variety of nutrients in complementary food, the time to start the complementary feeding also need to be considered. Starting the complementary feeding at the right time has a positive effect on child's development. Children who did not receive complementary foods in time were more likely to be obstructed compared to children who received complementary foods at 6 months old (Abeway, et al., 2018).

\section{REFERENCES}

Abebe Z, Desse G, Baye K (2017).Child feeding style is associated with food intake and linear growth in rural Ethiopia. Appetite. So195-6663(16) 30498-6. Doi: 10.1016/j.appet.2017.04.033

Abeway, Gebremichael B, Murugan R, Assefa M, Adinew YM (2018). Research article stunting and its determinants among children aged 6-59 months in Northern Ethiopia: A cross-sectional study Shiferaw. Hindawi Journal of Nutrition and Metabolism. Doi: https://doi.org/10.1155/2018/1078480.

Aguayo VM, Menon P (2016). Can water, sanitation and hygiene help eliminate stunting? Current evidence and policy implications. Matern Child Nutr. 12(1): 91-105. doi: 10.1111/mcn.12258

Aryastami NK, Shankar A, Kusumawardani N, Besral B, Jahari AB, Achadi E (2017). Low birth weight was the most dominant predictor associated with stunting among children aged 12-23 months in Indonesia. BMC Nutrition, 3:16. Doi:10.1186/s40795-017-0130-X Ayuningrum IY, Salimo H, Dewi YLR. (2017). Path analysis on gestational socio-economic determinants of nutritional status in children under five in Purworejo Regency, Central Java. Journal of Maternal and Child Health. 2(1): 30-41.

Batiro B, Demissie T, Halala Y, Anjulo A (2017). Determinants of stunting among children aged 6-59 months at KindoDidayeworeda, Wolaita Zone, Southern Ethiopia: Unmatched case control study. PLoS ONE 12(12): e0189106. DOI: https://doi.org/10.1371/journal.pone.0189106.

Brinkman HJ, Pee SD, Sanogo I, Subran L, Bloem MW (2009). High food prices and the global financial crisis have reduced access to nutritious food and worsened nutritional status and health. American Society for Nutrition (2010). Doi: 10.3945/jn.109.110767

Budhathoki SS, Bhattachan M, Yadav AK, Upadhyaya P, Pokharel PK (2016). Eco-social and behavioural determinants of diarrhoea in under-five children of Nepal: a framework analysis of the existing literature. Tropical Medicine and Health. 44:7. Doi: 10.1186/s41182-016-0006-9.

Cahyono F (2016). Faktor penentu stunting anak balita pada berbagai zona ekosistem di Kabupaten Kupang. Jurnal Gizi Pangan. ISSN 1978-1059. 11(1):9-18.

Cumming O, Cairncross S (2016). Can water, sanitation and hygiene help eliminate stunting? Current evidence and policy implications. Matern Child Nutr. 12(1): 91-105. Doi: 10.1111/mcn.12258.

deOnis M, Branca F (2016). Childhood stunting: a global perspective. Maternal and Child Nutrion. 12(1): 12-26. Doi: 10.1111/mcn.12231.

Desyanti C, Nindya TS (2017). Hubungan riwayat penyakit diare dan praktik 
higiene dengan kejadian stunting pada balita usia 24-59 bulan di wilayah kerja Puskesmas Simolawang, Surabaya. Amerta Nutrition. 243-251. doi: 10.2473/amnt.v1i3.2017.243-251

Dewey KG (2016). Reducing stunting by improving maternal, infant and young child nutrition in regions such as South Asia: evidence, challenges and opportunities. Matern Child Nutr. 12(1): 27-38. doi: 10.1111/mcn.12282.

Dewi IAKC, Adhi KT (2014). Pengaruh konsumsi protein dan seng serta riwayat penyakit infeksi terhadap kejadian stunting pada anak balita umur 24-59 bulan di wilayah kerja Puskesmas Nusa Penida III. Archive of Community Health. 3(1): 36-46. https://ojs.unud.ac.id/index.php/ach /article/view/21077.

Dinas Kesehatan NTT (2018). Profil kesehatan Nusa Tenggara Timur. Kupang.

Dinas Kesehatan Kota Kupang (2018). Profil Kesehatan Kota Kupang. Kota Kupang.

Fink G, Günther I, Hill K (2011). The effect of water and sanitation on child health: evidence from the demographic and health surveys 1986-2007. International Journal of Epidemiology. 40(5): 1196-1204. Doi: https://doi.org/10.1093/ije/dyr102.

Humphrey JH, Mbuya MNN, Ntozini R, Moulton LH, et al. (2018). Independent and combined effects of improved water, sanitation, and hygiene, and improved complementary feeding, on child stunting and anaemia in rural Zimbabwe: a cluster-randomised trial. Lancet Glob Health. 7(1): e132-e147. Doi: 10.1016/S2214-109X(18)30374-7.

Indriyani E (2018). Biopsychosocial determinants of stunting in children under five: A path analysis evidence from the Border Area West Kalimantan. Journal of Maternal and Child Health 3(2): 146-155. https://doi.org/10.26911/thejmch.2018.03.02.07.

Jamro B, Junejo AA, LalS, Bouk GR, Jamro $S$ (2012). Risk factors for severe acute malnutrition in children under the age of five year in Sukkur. Pakistan Journal of Medical Research. 51(4).

Kavosi E, Rostami ZH, Kavosi Z, Nasihatkon A, Moghadami M, Heidari M (2014). Prevalence and determinants of under-nutrition among children under six: a cross-sectional survey in Fars province, Iran. International Journal of Health Policy and Management. 3(2): 71.

Kementerian Kesehatan RI (2013). Riset kesehatan dasar. Jakarta: Kemenkes RI. http://www.depkes.go.id/resources/download/general/Hasil\%2oRisk esdas\%202013.pdf.

(2016). Infodatin: Pusat Data dan Informasi. Jakarta: Kemenkes RI.

(2018). Riset Kesehatan Dasar. Jakarta: Kemenkes RI. http://www.depkes.go.id/resources/download/inf o-terkini/materi_rakorpop_2018/Hasil\%20Riskesdas\%202018.pdf

Niga DM, Purnomo W (2016). Hubungan antara praktik pemberian makan, perawatan kesehatan, dan kebersihan anak dengan kejadian stunting pada anak usia 1-2 tahun di wilayah kerja Puskesmas Oebobo Kota Kupang. Jurnal Wiyata. 3(2).

Panjwani A, Heidkamp R (2017). Complementary feeding interventions have a small but significant impact on linear and ponderal growth of children in low- and middle-income countries: A Systematic Review and Meta-Analysis. The Journal of Nutrition. 147(11): 2169S-2178S. doi: 10.3945/jn.116.243857 . 
Prendergast AJ, Humphrey JH (2014). The stunting syndrome in developing countries. Paediatr Int Child Health. 34(4): 250-265. Doi: 10.1179/2046905514Y.0000000158.

Rah JH, Cronin AA, Aguayo VM, Coates S, Ahmed S (2015). Household sanitation and personal hygiene practices are associated with child stunting in rural India: a cross-sectional analysis of surveys. BMJ Journals. Doi: http://dx.doi.org/10.1136/bmjopen-2014005180.

Torlesse H, Cronin AA, Sebayang SK, Nandy R (2016). Determinants of stunting in Indonesian children: evidence from a cross-sectional survey indicate a prominent role for the water, sanitation and hygiene sector in stunting reduction. BMC Public Health. 16: 669. DOI: https://doi.org/10.1186/s12889-016-3339-8.

Rahman HF, Widoyo S, Siswanto H, Biantoro (2016). Faktor-faktor yang berhubungan dengan kejadian diare di
Desa Solor Kecamatan Cermee Bondowoso. Nurse Line Journal. 1(1).

Sulaiman AA, Bushara SO, Elmadhoun WM et al. (2018). Prevalence and determinants of undernutrition among children under 5-year-old in rural areas: A cross-sectional survey in North Sudan. J Family Med Prim Care. 7(1): 104-110. Doi: 10.4103/jfmpc.jfmpc_73_17.

UNICEF (2013). Improving Child Nutrition The achievable imperative for global progress. New York,United Nations Children's Fund (UNICEF). https://www.unicef.org/gambia/Improving_ Child_Nutrition_the_achievable_imp erative_for_global_progress.pdf.

WHO (2014). Global nutrition target 2025 Stunting Policy Brief. WHO/NMH/ NHD/14.3.https://www.who.int/nutri tion/publications/globaltargets2025_ policybrief_stunting/en/.

World Bank (2018). Joint child malnutrition estimates 2018 (UNICEF-WHOWB). http://datatopics.worldbank.org/child-malnutrition. 